Rabei G. Khamisy (Haifa)

\title{
THE TEMPLAR ESTATES IN THE TERRITORY OF ACRE*
}

esearchers of the Frankish period have a lot of difficulties in defining many
of the properties of the Templar Order, especially the rural properties, be-
cause of the loss of the Templar archives, and although it is reasonable to assume that the Templar Order owned as much property as the Hospitallers, only some of its holdings are known. ${ }^{1}$ Actually, our acquaintance with the order comes from the documents of other military orders, ecclesiastical bodies and a few other sources, such as descriptions by contemporary historians. This study will seek to locate the Templar properties in the region of Acre, or at least to identify the area in which the order owned properties, an element that has been missing in earlier studies.

The current research will deal with the plain of Acre between the Ladder of Tyre in the north and the Kishon River in the south, with the Acre-Safed highway connecting the two parts of the plain - the Western Upper Galilee plain in the north and the Western Lower Galilee plain in the south.

\section{THE NORTHERN PART}

We begin with a document issued in 1235 , which notes that the Teutonic order purchased a parcel of land from Johannes Griffus and his wife. The parcel was bounded on the east by the vineyard of Michael of Jerusalem, on the west by the garden of Pandolfi, on the north by the garden of Rolland, and on the south by the garden of Andree of Wienna and the garden of the Templars. The way to the parcel

* My great thanks to Professor Adrian Boas for commenting on the article, and to the Rural Research Center and its head Dr Shukrī 'Arrāf, for funding the editing of the article.

1 See for example about the Lordship of Caesarea S. Tibble, Monarchy and Lordships in the Latin Kingdom of Jerusalem 1099-1291, Oxford 1989, pp. 111-112, 119-120. See also M. Barber, The New Knighthood: A History of the Order of the Temple, Cambridge 1994, p. 89. 
came from the north, from the royal highway adjacent to the garden of the Hospitaller order. ${ }^{2}$ This transaction costs the Teutons 1,600 bezant, ${ }^{3}$ which seems to be paid for an extensive land. Four years later, in 1239, Giot and Iohan the sons of Michael of Jerusalem, sold a vineyard to the Teutonic order for 700 bezants. On the east it was bounded by the vineyard of Johannes of Conche, on the west by the garden of Rolland the Knight, on the south by the garden of the Teutons and on the north by the royal highway. ${ }^{4}$ It seems that this was the same vineyard of Michael of Jerusalem which was mentioned in the previous document from 1235. Another document dealing with the same transaction proves that the royal highway is actually the highway to Capharsin (Kafr-Yāsiff, map ref. 1659.2623). ${ }^{5}$ This proves that the lands in question are all located north of Acre-Safed highway and south of the highway to Kafr-Yāsif.

A document from February 1239 states that the Teutonic Order leased a parcel of land near Acre in a place called Mons Suspensorum. ${ }^{6}$ The land, leased from one Girardus, an abbot of the Mount Zion Church, is described as being bounded on the north by the lands of St. Lazarus of Bethany, on the south by the main highway, on the east by lands of the Templar Order and on the west by the garden of the Templars near the cemetery of St. Nicolas. Mons Suspensorum is identified with Tell Akko (Tall Napolion / Tall al-Fukhkhār) (map ref. 1585.2585), which is located east of the abovementioned cemetery. These lands can be connected to the previously mentioned lands. It seems that the Templar garden was the same property mentioned in both transactions, from 1235 and from February 1239.

2 Tabulae Ordinis Theutonici ex tabularii regii Berolinensis codice potissimum, ed. E. Strehlke, Berlin 1869 (repr.: Toronto 1975), pp. 63-64, no. 80.

3 Ibid., p. 123, no. 128.

4 Ibid., p. 70 , no. 88 .

5 Ibid., p. 123, no. 128. For identification see B. Bagatti, Ancient Christian Villages of Galilee, Jerusalem 2001, p. 149; K. G. Beyer, Die Kreuzfahrergebiete Akko und Galilaea, Zeitschrift des Deutschen Palästina-Vereins 67 (1945), p. 204; R. Frankel, Three Crusader Boundary Stones From Kibbutz Shomrat, Israel Exploration Journal 30 (1980), p. 201; D. Pringle, The Churches of the Crusader Kingdom of Jerusalem, 4 vols., Cambridge 1993-2009, here vol. 4, p. 132; E. Rey, Les Colonies franques de Syrie aux XII et XIII siécles, Paris 1883, p. 476.

6 Tabulae (as n. 2), pp. 68-69, 123, nos. 86, 128.

7 For identifications see Pringle (as n. 5), here vol. 4, p. 120. Maps from the $18^{\text {th }}$ and $19^{\text {th }}$ centuries as well as few maps from the beginning of the twentieth century show a road running south of the hill (B. Dichter, The Maps of Acre: An Historical Cartography, Acre 1973, pp. 44, 124, $141-143,146-147,150,152,157,159-162,192)$, and it seems that the road of these centuries is the same one of the twelfth and thirteenth centuries. This evidence could strengthen the identification of the hill with the thirteenth century Mons Suspensorum which was describes as being to the north of the main highway. 
On 3 April 1245, the two brothers, the knights Johannes and Symon, with the approval of their mother Agatha, sold properties to the Hospitallers, among them, three carrucas $^{8}$ of land that were bounded on the east by the lands of the Hospitaller village of Coquet (Kwikāt, map ref. 1642.2639) ${ }^{9}$, on the north by the lands of St. Samuel, on the south by the lands of the Hospitallers and on the west by the lands of St. Thomas and the lands of the Templars. ${ }^{10}$

In a later document, from 1277, a village in the region of Acre called Somelaria was specified as Templar. ${ }^{11}$ Somelaria is actually the village of as-Smiriyya (map

8 The size of the carruca is still not known. Prawer assumed that it could be either a measure of cultivated land (a "local" carruca) the same size as one Arabic faddān (734 sq m in the Jerusalem mountain regions, and almost twice in the plain), or an "official" carruca used for tax purposes, which was $389,717 \mathrm{sq} \mathrm{m}$, approximately 39 hectares (390 dunams). This calculation of the "official" carruca was done based on the information appearing in a marginal note of a document dated April 1195 (Tabulae (as n. 2), p. 27, no. 31). However, Prawer evaluated the carruca at an average of $35 \mathrm{ha}$, the average between his calculation and that of Emmanuel Rey (31.25 ha) who based his research on the same document. Boas provides some archaeological finds in order to strengthen the suggestion regarding the "local" carruca. In contrast, Ellenblum, doubting the reliability of the marginal note mentioned above, suggested that the carruca was no more than two ha. (20 dunams). For discussions, researches and comparison with the Arabic faddān see A. Boas, Domestic Settings: Sources on Domestic Architecture and Day-to-Day Activities in the Crusader States, Brill 2010, pp. 327-328; R. Ellenblum, Frankish Rural Settlement in the Latin Kingdom of Jerusalem, Cambridge 1998, pp. 98-99, 185; J. Prawer, Crusader Institutions, Oxford 1980, pp. 121, 121 n. 67, 157-159. About the faddān see S. 'Arrāf, al-Qarya al- 'arabiyya al-falastịniyya, Mi 'ilyā 1996, pp. 107-108; J. Ḥanīn Bik, al-Atyā̄n wa'l-ḍarā'ib fì al-quṭr al-mașrī, Būlāq 1904, pp. 107-110; M. Ramzī, al-Qāmūs al-jughrāfì lil-bilād al-mișriyya min 'ahd qudamā' al-mișriyyin ilā sanat 1945, 5 vols., al-Hay'a al-Mișriyya al- 'àmma lil-Kitāb 1994, here vol. 1, p. 10. Based on the abovementioned researches, the current study suggests that the local carruca was almost 6 dunams in the plain and the official carruca was as suggested by Prawer, 35 ha.

9 For the identification of the village see Beyer (as n. 5), pp. 202 n. 3 202, 207, 213; R. Frankel, Topographical Notes on the Territory of Acre in the Crusader Period, Israel Exploration Journal 38 (1988), p. 251, fig. 1; R. Frankel, N. Getzov, M. Aviam and A. Dagani, Settlement Dynamics and Regional Diversity in Ancient Upper Galilee: Archaeological Survey of Upper Galilee, Israel Antiquities Authority, Report 14, Jerusalem 2001, p. 13, no. 35; C. N. Johns, Palestine of the Crusaders: A Map of the Country on Scale 1: 350,000 with Historical Introduction and Gazetteer, Survey of Palestine, Jaffa 1940, map; D. Pringle, Secular Buildings in the Crusader Kingdom of Jerusalem: An Archaeological Gazetteer, Cambridge 1997, pp. 64, 144 map 3; idem, Churches (as n. 5), here vol. 4, p. 163; J. Riley-Smith, The Knights of St John in Jerusalem and Cyprus c. 1050-1310, A History of the Order of the Hospital of St John of Jerusalem, vol. 1, London 1967, p. 483, map 3, 486 .

10 Cartulaire général de l'Ordre des Hospitaliers de Saint-Jean de Jérusalem, 1100-1310 (further as Cart. Hosp.), ed. J. Delaville Le Roulx, 4 vols., Paris 1894-1905, here vol. 2, pp. 627-628, no. 2353.

11 Urkunden zur älteren Handels- und Staatsgeschichte Venedige, eds. G. L. Tafel, G. M. Thomas, 3 vols., Vienna 1856-1857, here vol. 3, p. 153, no. 369. 
ref. 1591.2641) which is located 4.5 kilometers due west of the abovementioned Kwikat. ${ }^{12}$ If the abovementioned carrucas were of the second type suggested by Prawer (the "official" carruca), ${ }_{13}^{13}$ the area mentioned in the April 1245 document would have been one square kilometer in size and thus, it would extend westward to a point very close to Somelaria. If so, it would seem that the Templar lands mentioned in the 1245 document are none other than the lands of Somelaria. That could mean that Somelaria was Templar property several decades before 1277 and perhaps even before 1245 .

Whether the carrucas were of the first type suggested by Prawer, or the size posited by Ellenblum and by the current research, ${ }^{14}$ the area would comparatively have been very small (6-60 dunams), as might the Templar lands to the west have been. But in both case, the Templar lands were in the west - toward Somelaria.

The question is which size of carruca is more suitable in the case in question here. On the one hand it seems that every village on the Western Galilee had its own lands, measuring from three to five square kilometers, ${ }^{15}$ and several landowners, such as Johan Costa and Johan Marran, possessed areas of between one and two square kilometers and perhaps a bit more (see discussion below). Thus, the two brothers Johannes and Symon, may also have owned such extensive lands. On the other hand, the properties in the 1245 document, which were sold to the Hospitallers for 600 bezants, included a house and a barn together with the three carrucas. That sum seems very small if the carrucas were the larger-size measurement, even if most of the money was for the land and not for the house and the barn. Thus, it could be suggested that in this specific sale, the carrucas were of the smaller size. In any case, this is the earliest information we have about Templar property, which can be identified as very close to Somelaria.

Another document important to our study, issued on 3 May 1250, noted that the Genoese community owned two parcels of lands in the Acre Plain. The bigger of the two was in the region of Dochum (D'ùq, map ref. 1618.2520) ${ }^{16}$ and the

12 For the identification of Somelaria see D. Barag, A New Source Concerning the Ultimate Borders of the Latin Kingdom of Jerusalem, Israel Exploration Journal 29 (1979), p. 205; Beyer (as n. 5), pp. 208, 212-213; A. Boas, Archaeology of the Military Orders: A survey of the urban centres, rural settlement and castles of the Military Orders in the Latin East (c. 1120-1291), London-New York 2006, pp. 87-88; Ellenblum (as n. 8), p. 209; Pringle, Churches (as n. 5), here vol. 2, p. 333 .

13 See n. 8 above.

14 See n. 8 above.

15 Unpublished Ph.d dissertation by the author. It will be published later as a book with Brill. Almost The same conclusion was derived by Prawer concerning the lordship of Tyre, cf. Prawer (as n. 8), p. 148.

16 For documents mentioning the place see Cart. Hosp. (as n. 10), vol. 2, pp. 7, 483, 486-487, 
other was in the lands of Cochetum (the abovementioned Kwikāt). In the document, the borders of the two parcels were marked with the letters IANUA (the city of Janaua) on all sides. ${ }^{17}$ Three of these stones have been found, and they, together with contemporary documents, enabled Frankel to locate some of the Templar, Hospitaller and Genoese properties in the region. ${ }^{18}$ It may be added that the Genoese land seems to have been very extensive - at least $1.5 \mathrm{~km}$ long on the eastwest axis according to the boundary stones.

A document from August 1255 notes that the Hospitaller Order paid 2,000 bezants to purchase two parcels of lands in the plain of Acre: the larger of the two was bordered on the north by the Genoese lands and the lands of the Church of the Holy Sepulchre, on the east by the royal highway to Cafriasin (Kafr-Yāsiff) on the west by a Templar vineyard and on the south by that same vineyard and highway. ${ }^{19}$

Earlier, in 1138, we are told that the Church of the Holy Sepulchre received two carrucas of land in a place called Mīmās (map ref. 1643.2633). ${ }^{20}$ If these two carrucas were of the larger type, the lands of the Church would measure almost $700 \times 1000 \mathrm{~m}$, thus increasing the likelihood that they were connected with the Genoese lands. If so, the Hospitaller land, which would have been extensive, would have been located south of the abovementioned two properties and almost one $\mathrm{km}$. south west of Mīmās. However, it is also reasonable that the Church of the Holy Sepulchre owned other lands in the region that for unknown reasons

489, nos. 1144, 2107, 2117, 2120; vol. 3, pp. 35, 58-59, nos. 3032, 3045. For researches see M. Benvenisti, The Crusaders in the Holy Land, Jerusalem 1970, pp. 248-252, 288; Beyer (as n. 5), pp. 207-208; Boas (as n. 12), pp. 83, 84, 86, 92, 199, 221, 232, 240, 250; Ellenblum (as n. 8), pp. 205-209; D. Pringle, Survey of Castles in the Kigdom of Jerusalem, 1989: Priliminary Report, Levant 23 (1991), p. 89 no. 7; idem, Secular (as n. 9), pp. 62-64; Riley-Smith (as n. 9), p. 446; idem, The Feudal Nobility and the Kingdom of Jerusalem, 1174-1277, London 1973, pp. 50-52; I. Shaked, Identifying the Medieval Flour Mills at Doq and Recordane, Cathedra 98 (2000), pp. 61-72 (Hebrew), English summary, p. 172.

17 C. Desimoni, Quatre titres des proprieties des gênois à Acre et à Tyr, in: Archives de l'Orient latin, 2 vols., Paris 1881-1884, here vol. 2, p. 24, no. 3; Regesta Regni Hierosolymitani (MXCVII-MCCXCI), ed. R. Röhricht, 2 vols., Innsbruck 1893-1904, p. 313, no. 1187.

18 Frankel, Three (as n. 5), pp. 199-201. For the other documents see below. Frankel reported that people from the community of Oshrat told him about the stones and their find-spots. However, he did not see them in situ (Frankel, pers. comm.), thus the location may be inaccurate and perhaps even quite misleading.

19 Cart. Hosp. (as n. 10), vol. 2, pp. 790-791, no. 2753; Regesta (as n. 17), vol. 1, p. 326, no. 1241.

20 Le Cartulaire du chapitre du Saint-Sépulcre de Jérusalem, ed. G. Bresc-Bauter, in: Documents relatifs à l'histoire des croisades, vol. 15, Paris 1984, pp. 95-96, no. 32; Regesta (as n. 17), vol. 1, pp. 44-45, no. 179. For discussion on the documents about Mīmās see Pringle, Churches (as n. 5), here vol. 2, pp. 32-33; idem, Churches (as n. 5), here vol. 4, p. 52. 
were not mentioned in their archive. ${ }^{21}$ This land could have lain either west or east of the Genoese lands, which would change the location of the Hospitaller land, moving it for almost one $\mathrm{km}$. to the west.

The Templar vineyard must have been very extensive to have been used to mark both the western and the southern boundary of the Hospitaller land. As indicated by the abovementioned three boundary stones, ${ }^{22}$ the Templar vineyard seems to have been directly adjacent to the southern side of the village of Somelaria, extending to the south and then turning eastward along the southern boundary of the Hospitaller land. This location is very close to the village of al-Makr (map ref. 1634.2599) which this study identifies as Templar. The village existed in the Frankish period and was therefore mentioned in the treaty between the Sultan Qalawūn and the authorities of Acre in 1283 as part of the Acre region; ${ }^{23}$ moreover, several Frankish remains were found in the village. ${ }^{24}$ This village was not mentioned in surviving Latin sources, perhaps because it had no relevance to landlords other than the Templars. The same could be true of al-Judayda (map ref. 1650.2592 ), just $1.5 \mathrm{~km}$ southeast of al-Makr; it, too, was not mentioned in the Latin sources, but was mentioned in the 1283 treaty. It should be noted that this region was one of the most documented throughout the Frankish period, especially the sections that belonged to the Hospitallers, Teutons and few landlords other than the Templars.

The second parcel of land that the Hospitallers purchase in the abovementioned document from August 1255 was bounded by the royal highway on the east, Hospitaller land to the south and the Camp del Temple ("Templar Field") to the north and west. This could be the same Campis Templi that the 1277 document places near Somelaria; ${ }^{25}$ it fits the description in that document nicely. In addition, the southern Hospitaller land could be the same garden which was mentioned in the document from 1235 which located it to the north of the highway to Kafr Yāsîf.

21 For example, the Church owned property near the spring of Tarshịha (map ref. 1754.2684), southeast of Castellum Regis (Tabulae (as n. 2), pp. 41, 120, nos. 49, 128), which was never mentioned in the Church's archives.

22 See n. 18 above. The three boundary stones must have been located on the southern side of the Genoese land as suggested by Frankel. If they were on the northern side, the lands of the Genoese would extend southward and get very far from Kwikāt in an area which seems to be out of "the lands of Kwikāt".

23 al-Qalqashandī, Shihāb al-Dīn Abu'l- Abbās Aḥmad Ibn 'Alī, Șubḥ al-a shā fì kitābat al-inshā, ed. 'A. R. Ibrāhīm, 14 vols., Cairo 1914-1928, here vol. 14, p. 55.

24 Frankel et al. (as n. 9), p. 11, no. 18. Survey by the author.

25 Urkunden (as n. 11), vol. 3, p. 158, no. 369. 
The royal highway seems to be the one to Kafr Yāsif mentioned in the same document; perhaps that is why, when the document mentions it again, no other settlement was cited as its destination. Because of its description as an eastern border, the highway should be somewhat on a north-south axis. Thus, it surely was not the highway connecting Acre with Safed, which runs east-west.

However, the coastal highway, connecting Haifa with Tyre, which is on a north-south axis, could serve as an eastern border. If this was the case, there are two possibilities; the first is that the second Hospitaller parcel described in the August 1255 document is located in the area north of Acre very close to the sea; the highway seems to have passed 1-2 kilometers from the sea, connecting Acre with Somelaria and points north. This also leads to the conclusion that the lands in question were in the region of Somelaria. The other possibility is that the parcels were south of Acre, in which case the most suitable location would have been between the Hospitaller Recordana in the south, the Templar Dochum in the north and west, and the royal highway in the east. ${ }^{26}$

Still, if that was the case, it is strange that none of the noteworthy places Dochum, Recordana and the Bellus River - were mentioned, as in the case of the Genoese lands, which were described as located in the lands of Dochum in the document dated 3 May $1250 .{ }^{27}$

However, this research believes that the highway is the same one to Kafr Yāsif and the Camp del Temple is the same one mentioned near Somelaria in 1277. It could therefore be suggested that the land under discussion here is located to the north of Acre. Once again, the Templars appear on the west, but this time also on the north (the region of Somelaria). This brings this Templar property very close to the abovementioned Templar vineyard which was mentioned in the same document - and a large contiguity of Templar holdings begins to emerge.

To the north of Somelaria only one village was mentioned in the 1283 treaty that is absent from Latin documentation - Al-Mazra' a (map ref. 1595.2654). It may not have been mentioned because it belonged to the Templars. Alternatively, it may have belonged to some other landowner but was built later than the

26 According to the map drawn by Mathew Paris in 1250-1259, the highway from Acre to Jaffa passed through the mill of Dochum. For discussion see Shaked (as n. 16), pp. 70-71. It seems that in this region, the royal highway was parallel to the Bellus River and almost $1 \mathrm{~km}$ east of it. In the place where it comes close to the Dochum mill, the highway turned westward and crossed the river over a bridge beside the mill.

27 It should be noted the according to the dispute on the water of the Bellus between the Templars and the Hospitallers (for documents see n. 16 above), it could be known that most of the lands along the Bellus and near it, belonged to the two locales of Dochum and Recordana. Thus, if the lands in question were between these two important places and close to the Bellus, the current research claims that they should be mentioned in some way. 
last time the nearby sites were mentioned in the Frankish documents, for example, a holding the documents call "the fief of the chamberlain" was on the northern boundary of Somelaria, and it belonged to owners other than the Templars. ${ }^{28}$ This research argues that Al-Mazra 'a's close proximity to Somelaria, its location to the south of Wādì al-Majnūni which was the southern border of the abovementioned fief, ${ }^{29}$ and its absence from the Latin documents indicates that it was Templar property.

The region north of al-Mazra' $a$, as far as al-Zỉb (Casal Imbert), as well as the region of Cochetum and Cafriasin, which were fully documented, contain no mention whatsoever of Templar Order. However, the Templar Order is mentioned with regard to properties concentrated in the region of Somelaria and to the south of it. Pringle for example suggested that Manshiyya (map ref. 1589.2597), which is located between Acre and Somelaris may belonged to the later. ${ }^{30}$ As noted, there are also some indications of Templar properties in the region of al-Makr. Thus, it could be suggested that the coastal plain of the Western Upper Galilee, between the Acre-Safed highway and the fief of the chamberlain, was divided among several owners, including the Templars. According to this theory, the Templars held extensive properties in western and southern parts of this region and were apparently one of the region's major property-owners.

\section{THE SOUTHERN PART}

A document related to Teuton holdings, dated 30 April 1242, notes that the Teutonic Order leased from the abbey of Mont Zion two vineyards located west of a place called "the king's mill", east of the Teutons' own land, north of the Bellus River and south of the main highway. ${ }^{31}$ It seems that the Teutons' land which bounded the two vineyards from the west was granted to them by Friderich the second in $1231 .{ }^{32}$ In the Acre area, there is only one place where the road and the river run parallel and close enough to each other to act as northern and southern property boundaries. This is a point very close to Tell Akko, just after the river turns westward. The area features the largest number of Ottoman-period mills in the re-

28 For the fief of the Chamberlain see Beyer (as n. 5), pp. 187, 190; Frankel (as n. 9), pp. 251, fig. 1, pp. 256-259; L. de Mas Latrie, Le Fief de Chamberlaine et les Chambellans de Jérusalem, Bibliothèque de l'École des Chartes 43 (1882), pp. 647-652.

29 Unpublished Ph.d dissertation by the author.

30 Pringle, Churches (as n. 5), here vol. 4, p. 233.

31 Tabulae (as n. 2), pp. 72-73, 123, nos. 91, 128.

32 Ibid., pp. 60-61, 123, nos. 76, 128. 
gion, and archaeological excavations at this site unearthed two possible Frankish walls with a floor containing thirteenth century pottery. ${ }^{33}$ This study identifies this place with the "king's mill" and with Fauconerie, a site that will be discussed below. Thus, the lands of the Teutons should be located south of the highway, south of Tell Akko and north of the Bellus River.

A document from December 1253 relates that Jean Laleman of Caesarea sold the village of Damor to the Hospitallers. ${ }^{34}$ The document places Damor, which has been identified with the Arabic al-Dāmūn (map ref. 1675.2536), ${ }^{35}$ south of Broet (al-Birwa, map ref. 1672.2567), ${ }^{36}$ east of Turoni Dominae Joiette (Tall Kīsān, map ref. 1644.2533) ${ }^{37}$ and west of Cabor (Kābūl, map ref. 1700.2526). ${ }^{38}$ According to the document, all of these properties belonged to Hospitaller Order. The Templar villages of Careblier and Tatura bounded Damor on the south.

Clermont-Ganneau identified Careblier with Kh. al-Ṭira (map ref. 1662.2509), and Tatura with the village of Tamra (map ref. 1697.2507). ${ }^{39}$ However, this research suggests the opposite: that Careblier was Tamra and Tatura was Kh. al-Tìra: A place called "Thamra al-Ṭurra” (which sounds very much like the name Tatura) appeared as a part of the Acre properties in the 1283 treaty. ${ }^{40} \mathrm{Tam}-$ ra was actually outside the boundaries of Acre and "Thamra al-Turra" (Tatura) should be identified with Kh. al-Ṭira which was inside the Acre boundaries. ${ }^{41}$

We may be able to identify the location of Careblier. A region called al-Kharrūba was mentioned several times during the double siege of Acre during the Third

33 Y. Lerer, 'Akko, Riduwan Gardens: Preliminary Report, Hadashot Arkheologiyot: Excavations and Surveys in Israel (2010) (http://www.hadashot-esi.org.il/report_detail_eng.asp?id=1389\&mag $\mathrm{id}=117)$.

34 Cart. Hosp. (as n. 10), vol. 2, p. 749-750, no. 2661; Regesta (as n. 17), vol. 1, p. 319, no. 1210.

35 C. Conder, Norman Palestine, Palestine Exploration Fund. Quarterly Statement (1890), p. 31; Frankel (as n. 9), p. 251, fig. 1; Johns (as n. 9), map; E. Rey, Supplément à l'étude sur la topographie de la ville d'Acre au XIII siècle, Mémoires de l'institut national de France, la société nationale des antiquaires de France 49 (1888), pp. 16-17.

36 For the identification of Beroueth see Beyer (as n. 5), p. 207; Frankel (as n. 9), p. 251, fig. 1; R. Röhricht, Studien zur mittelalterlichen Geographie und Topographie Syriens, Zeitschrift des Deutschen Palästina-Vereins 10 (1887), p. 251, n. 6; Rey, Colonies (as n. 5), pp. 474-475.

37 For the identification and researches see Ellenblum (as n. 8), pp. 195-197; Frankel (as n. 9), p. 251, fig. 1, p. 272; W. Fulco, Monnaies de Tell Keisan 1971-1974, Revue Biblique 82 (1975), p. 239; J-B. Humbert, E. Nodet, Tell Keisan (1979), Revue Biblique 86 (1979), p. 446, tab. 1, p. 447; Rey, Supplément (as n. 35), pp. 16-17.

38 For the identification see Ellenblum, Frankish, p. 194; Frankel (as n. 9), p. 251, fig. 1, p. 272; Johns (as n. 9), map; Rey, Colonies (as n. 5), p. 476.

39 Regesta (as n. 17), vol. 1, p. 319, n. 1-2, no. 1210.

40 Al-Qalqashandī (as n. 23), vol. 14, p. 55.

41 Barag, incorrectly assumed that Thamra al-Turra of 1283 is two places; Thamra is the village of Tamra and al-Ṭurra is Kh. al-Tịra (Barag (as n. 12), p. 204). 
Crusade, ${ }^{42}$ and according to the descriptions and the topography of the region, al-Kharrūba should be located east of Tall Kissān and north of Shafar'am, in the region of Tamra. Thus, the Frankish village of Careblier which seems to be derived from al-Kharrūba, ${ }^{43}$ could be identified with Tamra, Kh. al-Ṭīra, Rwīs (map ref. 1670.2522) or any other location in this region which is identified with the Arabic al-Kharrūba. But the Damor deed of sale sheds light on Careblier location. Tamra and Kh. al-Tīira are located on the same east-west line and could be described as southern borders of Damor.

Southwest of old Tamra, within the eponymous present-day town, a place called "Wa rat al-Kharrūba" appeared on Mandatory maps; ${ }^{44}$ the name perhaps harking back to the ancient al-Kharrūba, which in turn may reflected on the Frankish name "Careblier". Moreover, a place called al-Kharrūba was described as being "on the boundaries" between Acre and the Muslims in 1272, ${ }^{45}$ which could only mean the boundaries of Tamra at that time and in that region, because it was the only place located outside the boundaries of Acre and very close to it in that specific region. ${ }^{46}$ The other sites, Rwīs for example, could not be Careblier, because Rwīs is located north of Kh. al-Tīra and therefore could not be described as the southern border of Damor together with Kh. al-Tīira. Thus, according to the topography of the region and the absence of Rwis from the contemporary Latin documents, it could be suggested that Rwis was very small, that it belonged to the Templar Order and was located exactly on the boundary between The Templar properties of Tatura and the Hospitaller Damor.

A document from 11 February 1254 states that Johannes Marraim donated his lands in the Acre Plain to the Hospitallers. These lands are described as bounded on the east by the lands of the village of Hadia (Kh. al- Ayyādiyya, map ref. 1645.2576), which belonged to one Ronaldus Antelmi, from the west by the lands

42 For example see 'Imād al-Dīn al-Ișfahānī, al-Fath al-qussī fì al-fath al-qudsī, in: al-Mawsū'a al-shämiyya fì ta' rìkh al-hurūb al-șalībiyya, 40 vols., ed. S. Zakkār, Damascus 1995, here vol. 13, pp. 5981, 6002, 6023, 6079, 6106; Ibn Shaddād, Bahā' al-Dīn, Sìrat șalāh al-dìn al-ayyūbī, ed. M. Ḥ. Mușțafā, Ḥalab 2001, pp. 31, 121, 133, 134, 156, 179, 181; A. Tatcher, Horbat 'Uza and the Medieval Historical Sources, Israel Antiquities Authority 42 (2009), p. 108.

Both words, Latin Careblier and Arabic Kharrüba means the Carob tree.

44 Mandatory map of Acre 1: 20,000 (sheet 15/25, 16/25).

45 Qirțāy al-Khāzindārī, Ta 'rìkh majmū 'al-nawādir mimmā jarā li'l 'awā'il wa'l awākhir, ed. H-A. Hein, M. al-Ḥagharī, Beirut 2005, p. 149.

46 For the boundaries of Acre in 1283 see Barag (as n. 12). However, the author has slightly modified Barag's suggested boundaries (an article by the author on the 1283 boundaries will be published soon). See R. G. Khamisy, The Treaty of 1283 Between Sultan Qalawün and the Frankish Authorities of Acre: A New Topographical Discussion, Israel Exploration Journal (forthcoming)). It may be suggested that the 1283 boundaries are very similar to those of 1272 . 
of Johannis Coste, on the north by the highway at a point place very close to the hill that was called Turonis Saladini (Kh. al-T anțūr, map ref. 1631.2581) in the above document and on the south by the Templar land. ${ }^{47}$ In a document dated 19 March 1255, that same Johannis Coste (in the later document named Johannes Costa) donated his parcel of land to the Hospitallers. According to the document, that land was bordered from the east by the land the Hospitallers had given by Johannis Marran (called in the second document "Johannis Marraim"). On the west was bordered by the Genoese lands, on the north by the highway and from the south, again, by lands belonging to the Templar Order. ${ }^{48}$

Frankel was the only scholar who has studied these documents in depth in an attempt to locate some of these lands. ${ }^{49}$ More recently, Zghayyar proved that the lands that belonged to John Marran are still called Sahil Marrān "Marran's Field", thus he strengthening Frankel's suggestion about the location of these lands. ${ }^{50}$ According to Frankel's suggestion, which seems very accurate, the parcels in this section were quit extensive measuring almost two km. sq.

Another place called Fauconerie belonged to the Templar Order for some time. It was firs mentioned as a Templar property on 19 December 1262 as part of the dispute between the Templar and Hospitaller orders regarding the use of the water of the Bellus River. ${ }^{51}$ Based on this document, Peled suggested that Fauconerie was located near the Bellus and close to its estuary, ${ }^{52}$ meaning that Fauconerie must have been near Tell Akko. ${ }^{53}$

47 Cart. Hosp. (as n. 10), vol. 2, pp. 772-773, no. 2714; Regesta (as n. 17), vol. 1, p. 320, no. 1212; for identification of Hadia see Frankel (as n. 9), p. 251, fig. 1, p. 261; Tatcher (as n. 42), p. 108; for Turonis Saladini see Frankel (as n. 9), p. 251, fig. 1, p. 271-272. Cart. Hosp. (as n. 10), vol. 2, p. 775 , no. 2721.

49 Frankel (as n. 9); idem (as n. 5).

50 A. Zghayyar, Sahl Marrān: Mā Huwa Aṣl al-Ism?, in: Jubilee Volume in Honor to Dr. Najeeb Nabwani: Studies in Philosophy, Culture and Education, ed. S. Iliyan, Y. Avishur, N. Alkasem, M. Hugerat, Haifa 2007, pp. 355-388 (Arabic).

51 Cart. Hosp. (as n. 10), vol. 3, p. 59, no. 3045.

52 A. Peled, Sugar in the Kingdom of Jerusalem: A Crusader Technology between East and West, Jerusalem 2000, p. 137 (Hebrew).

53 Peled strengthened this logical suggestion in presenting Joinville's description of the region that mentions a place called Passe Pauline, which Joinville said was near the water and a sugar-cane plantation (Jean Sire de Joinville, Histoire de Saint Louis, ed. N. de Wailly, Paris 1868, p. 202; idem, Chronicles of the Crusades, Contemporary Narratives of the Crusade of Richard Coeur de Lion, by Richard of Devizes and Geoffrey de Vinsauf, and of the Crusade of Saint Louis by Lord John de Joinville, ed. H. G. Bohn, London 1848, p. 497). Peled posited that this location would have been very close to Acre. (Peled (as n. 52), pp. 137-138). But other contemporary sources (Cronaca del Templare di Tiro (1243-1314): La caduta degli Stati Crociati nel racconto di un testimone oculare, ed. L. Minervini, Naples 2000, p. 175; Les Gestes des Chiprois (Publications de la Société de l'orient latin, Série historique 5), ed. G. Raynaud, Genève 1887, p. 92; Ama- 
There seems to have been a connection between Fauconerie and a man named Rainaldum Falconarium, who, according to a document dated 16 March 1160, received properties from the king in order to develop the sugar industry and the mills in the Acre region. The document stated that the king also made a profit from this transaction. ${ }^{54}$ Later, in 1276, Eracles and Marino Sanudo claimed that a knight called Thomas de St. Bertino sold Fauconerie to the Templars without the king's permission, incurring the king's wrath. ${ }^{55}$ Thus, it is not known whether Fauconerie was owned by the Templars in 1262 , leased by them, or perhaps partially owned, while other parts belonged to Thomas leased from the king. ${ }^{56}$ In any case the Templar Order seems to have been active there. This research suggests identifying Fauconerie with the place called the "king's mill" in the document dated 30 April 1242, due to the relationship to the king in both cases and because the two places seem to be very close to Tell Akko according to the descriptions. ${ }^{57}$

According to the abovementioned documents, the area of the Templar Order on the plain of the Western Lower Galilee may be identified to a high degree of accuracy, especially in the second half of the thirteenth century. The northern most section of the plain was divided as follows: The Hospitallers owned the region of al-Birwa, in the easternmost part of this area. To the west, the region of al- 'Ayyādiyya seems to have belonged to Ronaldus Antelmi. West of that are the lands of John Marran and John Coata which were later owned by the Hospitaller Order. Still farther west were the lands of the Genoese, which according to Frankel extended all the way to the seashore. ${ }^{58}$

di. Chroniques d'Amadi et de Strambaldi, ed. L. de Mas Latrie, 2 vols., Paris 1891-1893, here vol. 1, p. 161), as well as Joinville’s description, reveal that Passe Pauline was the Rās al-Naqūra Pass on the Ladder of Tyre, as noted by Prawer (J. Prawer, Histoire du royaume latin de Jérusalem, 2 vols., Paris 1969-1970, here vol. 2, pp. 350-351, n. 65-66). Peled's suggestion concerning Fauconerie is right, but her suggestion about Passe Pauline was wrong.

54 Regesta (as n. 17), vol. 1, p. 90, no. 344. For discussion and details see Peled (as n. 52), p. 102.

55 Eracles, L'estoire de Eracles empereur, in: Recuel des Historiens des Croisades, Historiens occidentaux, 5 vols., Paris 1844-1895, here vol. 2, p. 474; Marino Sanudo, Liber Secretorum Fidelium Crucis super Terrae Sanctae Recuperatione et Conseruatione, ed. J. Bongars, Hanau 1611 (repr.: Jerusalem 1972), p. 226. See Regesta (as n. 17), vol. 1, pp. 343-344, no. 1312; Peled (as n. 52), p. 136; Prawer, Histoire, vol. 2, p. 513, n. 43.

56 For this see Prawer (as n. 53), vol. 2, p. 513, n. 43.

57 Röhricht err with identifying Fauconerie with a place called Shejret abu Saqr located on mount Carmel to the north west of 'Isifya. See Regesta (as n. 17), vol. 1, pp. 342-343, no. 1312, n. 1. Based on other contemporary documents, Prawer assumes it was located south-east of Caymont. See Prawer (as n. 53), vol. 2, p. 152, n. 47. However, the document from 19 December 1262 suggests differently. But, there could be two locales with similar names.

58 Frankel (as n. 9), p. 251, fig.1. 
However, based on the document from 1242, this research would suggest that the area of the "king's mill" might be west of the Genoese lands, in an area partly under Templar ownership. West of the "king's mill" came the two vineyards of the Teutonic Order, which seem to have reached very close to the eastern walls of Acre and the sea shore. Directly north of the Teutonic vineyards the document from February 1239 reveals that the Teutonic Order used the lands on Tell Akko, and that the land on the eastern and western sides of the tell belonged to the Templars. The eastern parcel is very close to the region of the "king's mill" west of the Genoese lands. On the westernmost part of this section, the parcels seem to be much smaller than those to their east due to the proximity to each other in this area of the river and highway, which border on these lands.

The second section to the south is also divided very clearly: Cabor, the easternmost locale, was Hospitaller. To the west is Damor, which also belonged to the Hospitallers and further west came Tall Kīsān; it, too, was Hospitaller property. West of these was a very broad parcel of Templar land, which was described in the abovementioned two documents from 11 February 1254 and 19 March 1255 as a southern border of the lands of John Marran and John Costa.

The Templar village of Dochum is located in the same region, it seems that this region was under Templar control, and that is why the document from 3 May 1250 described the Genoese lands as being on the "lands of Dochum" - intimating that Templar Dochum owed most of the lands there. The archives of the Genoese community and other contemporary Latin documents reveal that the Genoese owned only one parcel of land in this region (south of Acre-Safed highway), which was located in the northernmost part of the region, between the Hospitallers in the east and the Templars (Fauconerie) in the west. This Genoese land is located in a place which can be said to have been in the region of Dochum, especially if the Dochum holding was a large one.

It seems that the border between the two parts of the region described above was Wādī al-Halazūn, which flows from east to west through the plain. It is very interesting to note that in 31 may 1262 the Templars renounced all of their rights and possessions at Cabor for the Hospetallers and received rights and possessions at other places. ${ }^{59}$ This proves that the Timplars have had activities in Cabor and its vicinity and maybe owned it or parts of it. Cabor was mentioned on December 1253 as a Hospitaller village (see above). Thus, it is not known how and when

59 Cart. Hosp. (as n. 10), vol. 3, pp. 30-31, no. 3028. For brief discussion on this and other documents regarding the dispute between the two major orders see J. Riley-Smith, The Knights of St John in Jerusalem and Cyprus c. 1050-1310, London 1967, pp. 449-450; Tibble (as n. 1), p. 164. 
the Templars received their rights in the village and its vicinity, but it is reasonable to assume that this happened sometime between December 1253 and May 1262. It is also reasonable that the Templars owned these rights from owners other than the Hospitallers at unknown time, but these rights were lesser in size and importance than the Hospitaller rights and thus the village was identified as Hospitaller in $1253 .{ }^{60}$

The third section of the plain seems to have been divided between the two major orders: The Templars owned the extensive area of Kh. al-Tīra and Tamra to the east, along the southern side of the great Hospitaller lands of Cabor, Damor and Tall Kisann, while to the west of the Templar Lands were the extensive Hospitaller holdings of Kurdāna and, like the Templar region, this region was located along the southern side of the major Templar holdings at Dochum. Another hint that the region of Dochum and Recordana, including the Bellus River, was divided only between the Templars and the Hospitallers is the fact that no landowners are mentioned in the sources other than the two orders that were party to the dispute regarding the use of the river. This could mean that the damage the orders inflicted on each other during the thirteenth century affected no one else.

It is possible that the two Templar regions - Dochum and Tamra - were connected and thus created the largest property owned by a single entity in the Acre Plain. Directly south of the Tamra region is the village of Shafa 'amr. As we know from several contemporary documents, the village and perhaps its region belonged to the Templar Order for some time. ${ }^{61}$ If so, this region, which might have also encompassed 'Ibillīn (map ref. 1683.2475) was Templar property for long periods in the twelfth and thirteenth centuries and may also have been connected to their lands in the north (the region of Tamra). Between these lands and the region of Kurdāna, the Teutonic Order seems to have owned a comparatively small area, in the center of which was the village of Saphet (Safad'Adi, map ref. 1655.2477). ${ }^{62}$

A document issued between 1250 and 1261 mentioned the River of Acre and the Templar garden and vineyard. ${ }^{63}$

60 There were at least three kinds of rights in the fiefs and many villages such as Manueth and Cabor. These rights could be owned by several owners. For details see Ellenblum (as n. 8), pp. 200-202.

61 For documents and discussion see Pringle, Churches (as n. 5), here vol. 2, pp. 301-302.

62 One contemporary source proves that this village belonged to the Teutonic Order. See Itinéraires à Jérusalem et descriptions de la Terre Sainte redigés en français aux XI, XII et XIII siècles, ed. H. Michelant, G. Raynaud (Société de l'Orient Latin, série géographique 3), Geneva 1882, p. 198.

63 The Rule of the Templars: The French Text of the Rule of the Order of the Knights Templar, trans. and ed. J. M. Upton-Ward, Woodbridge 1992, p. 158, no. 616. 
It happened in Acre that our Master Brother Renaut de Vichier forbad any brother from the garden to eat or drink with another, unless it was water. And it happened shortly afterwards, that the brothers from the garden and the large vineyard left Acre and agreed together to eat supper at the large vineyard; and they remained so long at supper that it was night, and the brother from the large vineyard accompanied them a little on their way. And then the two brothers went together and the brother in charge of money accompanied the one from the Chene. And when they had passed the river of Acre, they found Saracens who attacked them and killed one of the brothers.

The way the garden and the vineyard were mentioned might suggest that the Templars owned only one garden in the region of Acre, perhaps an extensive one, but that they owned more than one vineyard. That would be the reason why the text refers to the garden as the only garden, ${ }^{64}$ while it mentions a large vineyard, which could mean that there were other, smaller ones.

If that was the case, the garden should be identified with the one mentioned above in the documents from 1235 and February 1239. If so, the large vineyard should be on the other side of the river, i. e., in the direction of Dochum, and that is why the two brothers are said to have passed the river when they went back to the garden. Later, in 1291 the Templar of Tyre mentioned a tower in Tell Akko overlooking these properties. ${ }^{65}$ This could help in recreating almost all the divisions along the highway to Kafr Yàsif in the part close to Acre. In addition, it strengthens the suggestion that there were extensive Templar properties southeast of Acre.

A Templar chapter house was mentioned as being in Recordana (Recordane according to the document $)^{66}:[\ldots]$ and he came before the chapter at Recordane, ${ }^{67}$ where another brother was sentenced to be expelled from the house according to the laws of the house [...].

This seems to have been the fortified mills of Dochum, which were located in the region of Recordana. The existence of the chapter house sheds light on the importance of the place, which seems to have been one of the most important for the Templars in the region. However, the historical and topographical evidence suggests that this locale was surrounded by properties of the Hospitaller Order and seems to have been separate from the great Templar region. In order to prove this

64 It was called "the garden".

65 Cronaca (as n. 53), p. 206; Les Gestes (as n. 53), p. 243. This tower of St. Spirit was also mentioned on December 1231 (Tabulae (as n. 2), pp. 60-61, 123, nos. 76, 128). For the suggestion see Pringle, Churches (as n. 5), here vol. 4, pp. 168-169.

66 Upton-Ward (as n. 63), p. 159, no. 618.

67 The editor mistakenly identified Recordane with Shafa' amr (ibid., p. 159, n. 618.2), perhaps because the commander of the Templar order was mentioned as having been transferred from Acre to Shafar'am in 1250-1251 during the Crusade of Louis IX (Joinville (as n. 53), p. 173). 
we will again refer to the documents mentioning the dispute between the two orders. The Templars claimed in 1262 that the Hospitallers' use of the water for sugar cane irrigation affected Fauconerie, by raising the level of the sand there. ${ }^{68}$ The Hospitaller fields were actually located upriver; they seem not to have owned properties farther downriver. Otherwise they would be badly affected by such cultivation act. Moreover, in 1235 the Templars were allowed to carry out some work on the reservoir of their mill, although the reservoir was located in a Hospitaller area ${ }^{69}$ It could be asked why the Templars built their mill so close to Hospitaller property and used their own land to build the reservoir. The answer could be because they did not have lands there other than the lands where the mill was located, which also seems to have been owned for this specific purpose. Moreover, the Hospitaller properties, which are well documented, included no property downriver, as noted. In addition to the historical evidence, the geographical situation did not allow the river to serve as a natural boundary between the parties. The river separates the plain into two parts - the western part, 2-3 km wide, contains a wide, sandy strip 1-2 km wide. Thus, only $1 \mathrm{~km}$ along the river is not covered by the sand. Part of this area along the river was marshy and extended in some places to width of much a few hundred meters from both banks. Thus, the western side of the river contained a long strip of cultivable land, a bit more than $500 \mathrm{~m}$ wide in average, located between the sandy and marshy strips. On the other hand, the eastern side of the river contained wide fields that were not affected by sea sand. ${ }^{70}$ Thus, it is reasonable to assume that both the Templars and Hospitallers owned lands on both sides of the river. In that case, the historical evidence suggests that the Templars owned properties in the northern half of this area, and the mill was located inside the Hospitaller, southern half.

Only two documents mentioned properties south of Kurdāna as far as the Kishon River; In 1164, the two brothers Rogerius and Johannes of Haifa, granted the Church of the Holy Sepulchre some lands on both sides of the "River of Haifa" near to the spring. ${ }^{71}$ Ellenblum identified the "River of Haifa" with the Kishon River. ${ }^{72}$ The spring is most likely the $\mathrm{Sa}$ ' àda spring (map ref. 1528.2439) which is the beginning of the perennial stream carrying the same name and meets the Kishon very close to Haifa. A village by the name "Sesset" appeared on April 1166 as

\footnotetext{
68 Cart. Hosp. (as n. 10), vol. 3, p. 59, no. 3045.

69 Ibid., vol. 2, pp. 483, 486-487, nos. 2107, 2117.

70 See Palestine Exploration Fund Map, Sheet V (1880); Mandatory map of Acre 1: 20,000 (sheet $15 / 25,16 / 25)(1946)$.

71 Le Cartulaire (as n. 20), pp. 260-261, no. 134.

72 Ellenblum, Frankish (as n. 8), p. 97.
} 
belonged to the Templum Domini. ${ }^{73}$ It was previously identified with Sa 'sa ' which is located in the Upper Galilee (map ref. 1873.2704) ${ }^{74}$ while this research suggest that Sesset is more likely Sāsā al-Siyāsiyya (Kh. Sa 'sa' (map ref. 1626.2423)), a locale mentioned in the treaty between the Mamlūks and the Franks in 1283 as belonging to Acre. ${ }^{75}$

Due to the absence of this region from the documents we have no idea to whom these lands belonged, but it is possible that some of them belonged to the Templars.

\section{Conclusion}

Although the Templar archive has been lost, and the order was mentioned only on few legal documents, this study has been able to locate two large areas belonging to this order, or in which the order was active in the Acre Plain (fig. 1). One of the areas was northeast of Acre on the southwestern side of the plain of the Western Upper Galilee. That area measured $6.5 \mathrm{~km}$ long and $3 \mathrm{~km}$ wide widening in its southernmost part where it turned east at least as far as al-Makr. The second area is located on the plain of the Western Lower Galilee. Running on an east-west axis, it is very long (almost $12 \mathrm{~km}$ ) and $3 \mathrm{~km}$ wide in average, perhaps wider in the area of Shafa' amr.

The Templar Order, like the Hospitallers, had no interest in the mountainous region of the Western Upper Galilee. That is why no contemporary documents mention properties of either order as being located in that region. The Templars owned the castle of Safed and its region - one of the most important and powerful castle in the Crusader Kingdom of Jerusalem. In fact, the Templar Order had been established to defend pilgrims and the Frankish Kingdom and thus, they owned almost all the strongholds along the pilgrim routes between Jaffa, Jerusalem and Jericho $^{76}$ as well as several fortresses on the highways and boundaries of the Kingdom, such as Gaza Atlil, Safed, Beaufort and others.

73 F. Chalandon, Un diploma inédit d'Amaury I roi de Jérusalem en faveur de l'abbaye du TempleNotre-Seigneur (Acre, 6-11 avril 1166), Revue de l'Orient latin 5 (1900-1901), pp. 314-315; Regesta (as n. 17), vol. 2, pp. 25-26, no. 422a.

74 Pringle, Churches (as n. 5), here vol. 4, pp. 70, 173.

75 Al-Qalqashandī (as n. 23), vol. 14, p. 55.

76 See D. Pringle, Templar Castles on the Road to the Jordan, in: The Military Orders: Fighting for the Faith and Caring for the Sick, ed. M. Barber, Aldershot 1994, pp. 148-166; idem, Templar Castles between Jaffa and Jerusalem, in: The Military Orders, vol. 2: Welfare and Warfare, ed. H. Nicholson, Aldershot 1998, pp. 89-109. For summary about the reasons of the order's establishment see Boas (as n. 12), pp. $2-4$. 
Despite the fact that the plain of Acre has no strategic importance, the Templars had holdings along the region's highways, which connected Haifa and Tyre, ${ }^{77}$ and along the pilgrim highway that linked Acre with Nazareth. ${ }^{78}$ This could somewhat prove that also in the Acre plain, the Templar Order respected its rules and the basis of its establishment, and thus it was one of the major owners of the lands along the Highways and not in the other places of the plain. However, the large holdings of the Templar Order on the plain might shed light on the order's agricultural activity. It seems that the Templar Order, like the Hospitallers and Teutons, was very involved in agriculture. Indeed, it seems that the order was interested in properties on the plain for economic reasons rather than strategic and military ones.

77 The Templar Order owned the Pilgrim's Castle south of Haife, and according to Theodericus (Libellus de Locis Sanctis, in: Corpus Christianorum, Continuatio Mediaeualis, ed. R. B. Huygens, Turnholt 1966-(????), vol. 139, p. 185; idem, in: Palestine Pilgrims' Text Society Library, 13 vols., London 1890-1897, here vol. 5, p. 59) the Templars also owned a castle on the top of the Carmel. South of Acre they owned Dochum and its fortified mills, and to the north they owned Somelaria which may have contained a kind of stronghold.

78 On that highway to Nazareth the Templar Order owned Dochum, the fortified mills and Shafa'amr. 


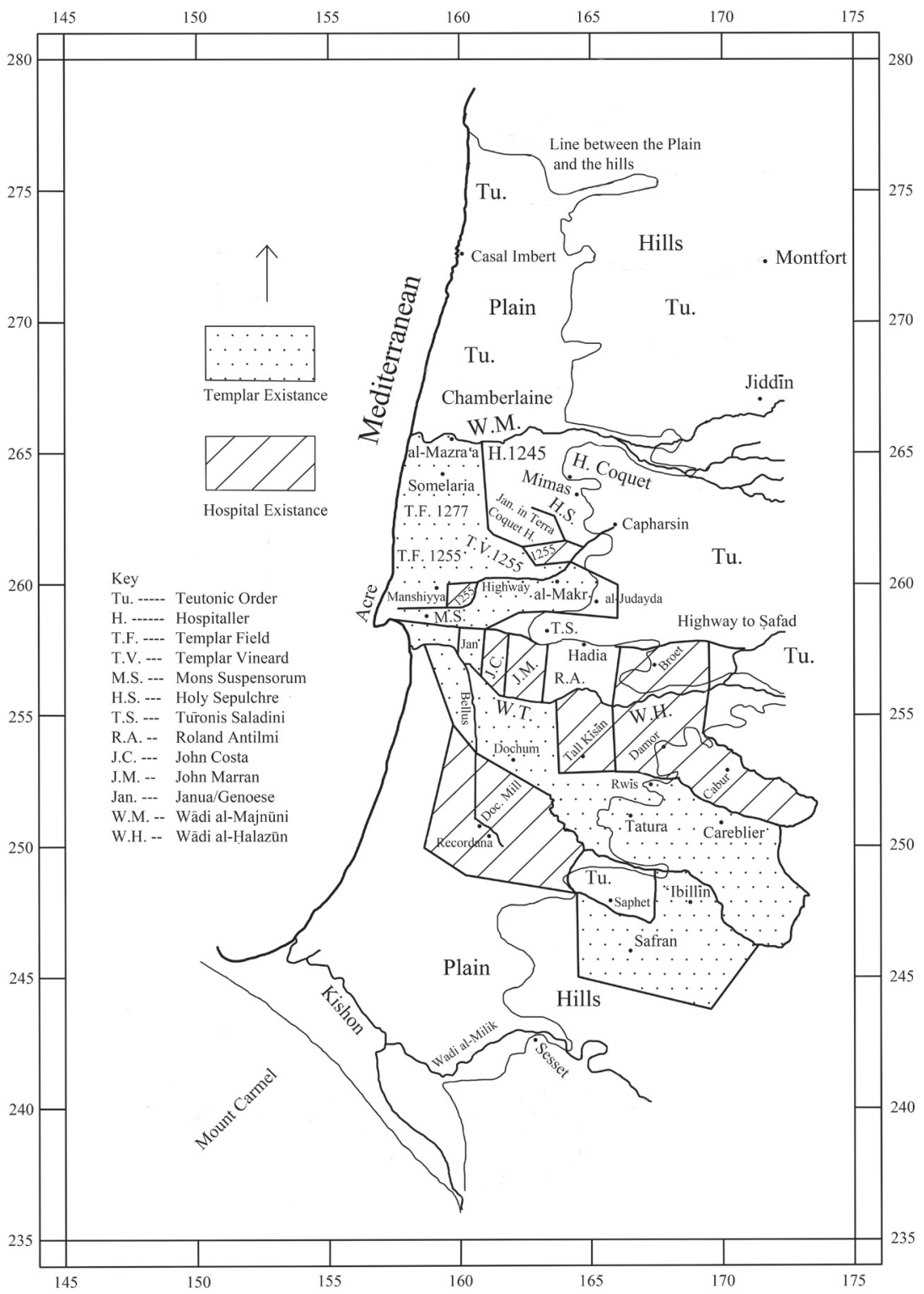

Fig 1. Map of the region 
